\title{
RITUAL TOLAK BALA PADA MASYARAKAT MELAYU \\ (KAJIAN PADA MASYARAKAT PETALANGAN KECAMATAN PANGKALAN KURAS KABUPATEN PELALAWAN)
}

\author{
Hasbullah, ${ }^{1}$ Toyo, ${ }^{1}$ dan Awang Azman Awang Pawi ${ }^{2}$ \\ ${ }^{1}$ Universitas Islam Negeri Sultan Syarif Kasim Riau, Indonesia \\ ${ }^{2}$ Universiti Malaya, Malaysia \\ hasbullah@uin-suska.ac.id
}

\begin{abstract}
This study stepped forward from phenomenon of the catastrophe rejection ritual practiced by the people of Petalangan nevertheless they had been all Moslems. The ritual reinforced a religious syncretism in which one might be able to find elements of Islam, Hinduism and Buddhism, as well as animism and dynamism. This study aims at explaining the purpose of the implementation of the reinforcements, the unification of Islam in the ritual of catastrophe rejection, and why this ritual was still maintained by the community. A qualitative approach was used to observe and to collect the data as well as the use of interview and documentation. The descriptive data analysis technique was used. Results showed that the ritual of catastrophe rejection done by the society aimed to avoid disaster either for individual, society, or the village. Then, this ritual was also called "village." The element of Islam was added in such a way which was wrapped by religious fiesta for the repulsive reinforcement. Due to community's lack of understanding on Islamic teachings and low level of education, as well as strong psychological relationship with the surrounding community, this ritual was still persisted.
\end{abstract}

Keywords: Ritual, Catastrophe Rejection, Petalangan, and Pelalawan.

\begin{abstract}
Abstrak
Kajian ini berpijak dari adanya fenomena masih dilaksanakannya ritual tolak bala oleh masyarakat Petalangan, padahal mereka semuanya sudah beragama Islam. Ritual tolak bala merupakan salah satu bentuk sinkretisme agama, di mana dalam ritual tersebut dapat ditemukan unsur-unsur Islam, Hindu dan Budha, serta animisme dan dinamisme. Kajian ini bertujuan untuk menjelaskan tujuan dari pelaksanaan tolak bala, perpaduan Islam dalam ritual tolak bala, serta mengapa ritual ini masih tetap dipertahankan oleh masyarakat. Adapun pendekatan yang digunakan adalah pendekatan kualitatif dengan teknik pengumpulan data observasi, wawancara, dan dokumentasi. Sedangkan teknik analisis data yang digunakan adalah deskriptif. Hasil kajian ini memperlihatkan bahwa ritual tolak bala dilakukan oleh masyarakat dengan tujuan agar terhindar dari bencana, baik secara individu, masyarakat, maupun kampung. Ritual ini disebut juga dengan mengobati kampung. Unsur Islan ditambahkan sedemikian rupa dalam ritual ini yang dibungkus dengan cara kenduri tolak bala. Bertahannya ritual ini dikarenakan kurangnya pemahaman masyarakat terhadap ajaran Islam serta rendahnya tingkat pendidikan masyarakat, serta masih kuatnya hubungan psikologis masyarakat dengan alam sekitar.
\end{abstract}

Kunci: Ritual, Tolak Bala, Petalangan, dan Pelalawan. 


\section{Pendahuluan}

Dalam hidup ini manusia menghadapi berbagai persoalan dan tantangan, seperti gagal panen, bencana alam, penyakit, dan sebagainya. Manusia tidak bisa lepas dan lari dari persoalan tersebut. Oleh karena itu, menghadapi dan mencari solusi atau penyelesaian untuk mengatasi persoalan tersebut harus dilakukan. Ada banyak cara yang dilakukan oleh manusia, salah satunya berdamai dengan alam melalui pelaksanaan serangkaian ritual atau upacara. Meskipun manusia berada dalam zaman yang serba maju dan canggih, namun cara seperti ini tidaklah ditinggalkan sepenuhnya oleh sebagian kelompok masyarakat. Bagi mereka melaksanakan ritual untuk berdamai dengan alam adalah jalan untuk mencapai kehidupan yang damai, aman, tenteram, dan sejahtera. Ritual tersebut secara umum bagi masyarakat Riau dikenal dengan istilah "tolak bala". Ritual ini dilaksanakan dalam rentang waktu tertentu dan dengan sebab tertentu.

Fenomena seperti dijelaskan di atas masih ditemukan di masyarakat Petalangan Kabupaten Pelalawan Provinsi Riau. Meskipun harus diakui, sebenarnya fenomena ini pada masa lalu juga dilaksanakan oleh berbagai suku bangsa di Indonesia. Hanya saja sejalan dengan perkembangan zaman dan kemajuan teknologi, tradisi ritual ini secara perlahan mulai ditinggalkan. Bagi masyarakat Petalangan, pelaksanaan ritual tolak bala merupakan suatu tradisi yang penting dan tidak bisa ditinggalkan. Meskipun mereka sudah menganut agama Islam, praktik ini masih tetap bertahan. Meminjam istilah Mohd. Taib Osman, ritual tolak bala dapat dikelompokkan ke dalam "Islam Populer". ${ }^{1}$ Islam populer merupakan hasil dari dialektika antara agama (Islam) yang dianut oleh masyarakat dengan kepercayaan lokal.

Ritual tolak bala mengandung kepercayaan terhadap adanya kekuatan alam yang harus

\footnotetext{
${ }^{1}$ Mohd. Taib Osman (ed.), Masyarakat Melayu Struktur, Organisasi dan Manifestasi (Kuala Lumpur: Dewan Bahasa dan Pustaka, 1989), 192-193.
}

didukung dan dipertahankan untuk mencari jalan terbaik dalam meneruskan kehidupan sehari-hari masyarakat agar dijauhkan atau terhindar dari marabahaya. Masyarakat Petalangan memandang bahwa ritual tolak bala merupakan suatu bentuk upacara yang mengandung kepercayaan mengobati kampung. Ritual ini merupakan perilaku simbolis atau tindakan sekaligus sebagai wujud ekspresi jiwa mereka dalam menjalin hubungan dengan penghuni dunia gaib. Setiap awal bulan masehi masyarakat Petalangan di Desa Betung Kecamatan Pangkalan Kuras Kabupaten Pelalawan melaksanakan ritual ini sebagai warisan tradisi nenek moyang mereka dengan tujuan untuk mendapatkan keselamatan atau terhindar dari gangguan makhluk gaib. Praktik ritual tolak bala mengandung unsur yang berasal dari agama Islam, yaitu doa yang dibacakan oleh tokoh agama. Namun, ritual ini juga melibatkan dukun sebagai pelaksana ritualnya. Dengan demikian, ritual ini merupakan satu bentuk dari perpaduan unsur Islam dengan kepercayaan lokal.

Pergulatan agama dan tradisi lokal sudah lama menjadi objek kajian, baik dalam tinjauan sosiologis maupun antropologis. Geertz ${ }^{2}$ memandang bahwa agama dan budaya berjalan secara membalas, artinya pada satu sisi agama memberi pengaruh terhadap budaya dan pada saat yang sama budaya juga mempengaruhi agama. Dari sinilah terjadinya keragaman dalam kebudayaan Islam, di mana setiap daerah mempunyai corak atau ciri khas sendiri. Hal ini tentu saja merupakan konsekuensi dari bagaimana Islam masuk di daerah tersebut. Kajian komparatif Islam di Indonesia dan Maroko yang dilakukan oleh Clifford Geertz, ${ }^{3}$ misalnya membuktikan adanya pengaruh budaya dalam memahami Islam. Di Indonesia, Islam menjelma menjadi suatu agama yang sinkretik, sementara

${ }^{2}$ Clifford Geertz, Kebudayaan dan Agama (terjemahan) (Yogyakarta: Kanisius, 1992), 1-49.

${ }^{3}$ Clifford Geertz, Islam Observed Religious Development in Morocco and Indonesia (Chicago \& London: The University of Chicago Press, 1971). 
di Maroko, Islam mempunyai sifat yang agresif dan penuh gairah.

Kajian tentang hubungan antara agama dengan budaya sudah banyak dilakukan oleh para ahli. Berdasarkan kajian yang dilakukan oleh para ahli, paling tidak dapat dikategorikan ke dalam tiga tipologi kajian Islam dalam konteks lokal, yaitu yang bercorak sinkretik, akulturatif, dan kolaboratif. Corak pertama antara lain dapat dilihat dalam kajian yang dilakukan oleh Geertz, ${ }^{4}$ Mahmud Manan, ${ }^{5}$ Masyudi,${ }^{6}$ dan Edwin Fiatiano, et.al. ${ }^{7}$ Di antara tulisan yang secara jelas menggambarkan mengenai sinkretisme ialah Andrew Betty, ${ }^{8}$ Suripan Sadi Hutomo, ${ }^{9}$ dan Neils Mulders. ${ }^{10}$ Corak kedua antara lain dapat dilihat dari kajian Hefner, ${ }^{11}$ Woodward, ${ }^{12}$ Muhaimin AG, ${ }^{13}$ Erni Budiwanti, ${ }^{14}$ Masdar Hilmy, ${ }^{15}$ Arifuddin Ismail, ${ }^{16}$ Norhasan, ${ }^{17}$ Ahmad Kholil, ${ }^{18}$ Hikmatul

${ }^{4}$ Clifford Geertz, Abangan, Santri, Priyayi dalam Masyarakat Jawa (terjemahan) (Jakarta: Pustaka Jaya, 1989).

${ }^{5}$ Mahmud Manan, "Nilai-nilai Budaya Peninggalan Majapahit dalam Kehidupan Masyarakat di Trowulan Mojokerta" (Surabaya: Lembaga Penelitian IAIN Sunan Ampel, 1999).

'Masyudi, "Ziarah ke Makam Islam Sunan Ampel Surabaya," Madaniyya, Jurnal Sastra dan Sejarah II, no. 2 (1999): 41-51.

${ }^{7}$ Edwin Fiatiano, et.al., "Makam Sunan Giri sebagai Objek Wisata Budaya", dalam Kumpulan Abstrak Hasil Penelitian Universitas Airlangga (Surabaya: Lembaga Penelitian Universitas Airlangga, 1998).

${ }^{8}$ Andrew Betty, "Adam and Eve and Vishnu: Syncretism in the Javanese Slametan," The Journal of Anthropological Institute 2 (1996).

${ }^{9}$ Suripan Sadi Hutomo, Sinkretisme Jawa Islam (Yogyakarta: Bentang Budaya, 2001).

${ }^{10}$ Neils Mulders, Agama, Hidup Sehari-Hari dan Perubahan Budaya (Jakarta: Gramedia Pustaka Utama, 1999).

${ }^{11}$ Robert W. Hefner, Hindu Javanese: Tengger Tradition and Islam (Princeton: Princeton University Press, 1985).

${ }^{12}$ Mark R. Woodward, Islam Jawa Kesalehan Normatif Versus Kebatinan (terjemahan) (Yogyakarta: LkiS, 1999).

${ }^{13}$ Muhaimin AG., Islam Dalam Bingkai Budaya Lokal Potret Dari Cirebon (Jakarta: Logos, 2001).

${ }^{14}$ Erni Budiwanti, Islam Sasak, Islam Wetu versus Wetu Telu (Yogyakarta: LkiS, 2000).

${ }^{15}$ Masdar Hilmy, "Akulturasi Islam ke dalam Budaya Jawa: Analisis Tekstual-Kontekstual Ritual Slametan," Jurnal Paramedia III, no. 1 (2001): 34-83.

${ }^{16}$ Arifuddin Ismail, Agama Nelayan: Pergumulan Islam dengan Budaya Lokal (Yogyakarta: Pustaka Pelajar, 2012).

${ }^{17}$ Norhasan, "Tradisi Kadiran: Kajian Terhadap Pola Ritual dan Makna Simbolisnya,” Jurnal Teosofi 2, no. 1 (2013): 50-66.

${ }^{18}$ Ahmad Kholil, "Seblang dan Kenduri Masyarakat Desa Olehsari: Relasi Ideal Antara Islam dan Budaya Jawa di Banyuwangi," El-HARAKAH 12, no. 2 (2010): 13-13.
Mustaghfiroh dan Muhamad Mustaqim, ${ }^{19}$ dan Roibin. ${ }^{20}$ Demikian pula tulisan Hendro Prasetyo, ${ }^{21}$ Headley, ${ }^{22}$ Taufik Abdullah, ${ }^{23}$ A. Mukti Ali, ${ }^{24}$ Nakamura, ${ }^{25}$ Abdul Munir Mulkhan, ${ }^{26}$ Noerid Halui Radam, ${ }^{27}$ dan Bartholomew. ${ }^{28}$ Sedangkan corak ketiga diwakili oleh kajian yang dilakukan oleh Nur Syam. ${ }^{29}$ Islam kolaboratif berada di dalam kategori Islam akulturatif dan Islam sinkretik, yaitu hubungan antara Islam dan budaya lokal yang bercorak akulturatif-sinkretik sebagai hasil konstruksi bersama antara agen (elit-elit lokal) dengan masyarakat dalam sebuah proses dialektika yang terjadi secara terus menerus.

Kajian-kajian di atas melihat pergumulan Islam dalam budaya lokal dalam berbagai aspek kebudayaan, baik yang meliputi beberapa aspek atau hanya satu aspek saja. Secara umum, beberapa kajian di atas terkait atau menjelaskan tentang upaya yang dilakukan manusia, baik dalam bentuk ritual maupun tradisi untuk mendapatkan keberkahan, murah rezeki, keberhasilan dalam pertanian, melaut, dan lain-lain. Kajian-kajian tersebut seperti dilakukan oleh Masyudi, Masdar Hilmy, Arifuddin Ismail, Norhasan, Ahmad Kholil, Roibin, dan Hikmatul Mustaghfiroh

\footnotetext{
${ }^{19}$ Hikmatul Mustagfiroh dan Muhamad Mustaqim, "Analisis Spiritualitas Para Pencari Berkah (Studi Atas Motivasi Peziarah di Makam Sunan Kalijaga Kadilangu Demak)," Jurnal Penelitian 8, no. 1 (2014): 143-160.

${ }^{20}$ Roibin, "Dialektika Agama dan Budaya dalam Tradisi Selamatan Pernikahan Adat Jawa di Ngajum, Malang," ElHARAKAH 15, no. 1 (2015): 34-47.

${ }^{21}$ Hendro Prasetyo, "Mengislamkan Orang Jawa: Antropologi Baru Islam Indonesia," Jurnal Islamika, no. 3 (1993): 74-84.

${ }^{22}$ Stepen Headley, "The Islamization of Central Java: The Role of Muslim Lineage in Kalioso," Studia Islamika 3, no. 2 (1997). 23Taufik Abdullah, "Islam dan Pembentukan Tradisi di Asia Tenggara: Sebuah Perspektif Perbandingan", dalam Tradisi dan Kebangkitan Islam di Asia Tenggara, Taufik Abdullah \& Sharon Siddique (Jakarta: LP3ES, 1988).

${ }^{24}$ A. Mukti Ali, "The Evolution of Islam in Indonesia," Cultures VII, no. 4 (1980): 109-118.

${ }^{25}$ Mitsuo Nakamura, Bulan Sabit Muncul dari Balik Pohon Beringin (terjemahan) (Yogyakarta: Gajah Mada University Press, 1983).

${ }^{26}$ Abdul Munir Mulkhan, Islam Murni pada Masyarakat Petani (Yogyakarta: Bentang Budaya, 2000).

${ }^{27}$ Noerid Halui Radam, Religi Orang Bukit (Yogyakarta: Semesta, 2001).

${ }^{28}$ John Ryan Bartholomew, Alif Lam Mim; Kearifan Masyarakat Sasak (Yogyakarta: Tiara Wacana, 2001).

${ }^{29}$ Nur Syam, Islam Pesisir (Yogyakarta: LkiS, 2005).
} 
dan Muhamad Mustaqim. Kajian yang penulis lakukan berbeda dari kajian-kajian di atas, karena ritual tolak bala tidak hanya berfokus kepada keselamatan pribadi, melainkan yang terpenting adalah keselamatan bagi keseluruhan masyarakat desa atau kampung. Di samping itu, kajian ini juga berbeda, baik dilihat dari sisi subjek, objek, maupun lokasi penelitian. Kajian ini ingin menjelaskan tujuan dari pelaksanaan ritual tolak bala, perpaduan Islam dengan budaya lokal dalam ritual bala, serta mengapa ritual ini masih tetap bertahan di tengah kemajuan zaman.

\section{Metode Penelitian}

Metode yang digunakan dalam penelitian ini adalah metode kualitatif. Metode ini mampu menangkap dan memahami keberadaan saling berhubungan antara berbagai gejala eksternal maupun internal yang terdapat dalam ritual tolak bala pada masyarakat Petalangan Kecamatan Pangkalan Kuras Kabupaten Pelalawan. Di samping itu, data-data yang diperlukan dalam penelitian ini bersifat deskripsi dan tidak memerlukan kuantifikasi, sehingga metode kualitatif dipandang tepat untuk digunakan. ${ }^{30}$ Melalui metode ini akan didapatkan datadata yang bersifat deskriptif, yakni apa yang dituturkan orang, baik lisan maupun tulisan dalam bahasa serta dalam peristilahannya. ${ }^{31}$

Penelitian ini mengambil lokasi Desa Betung Kecamatan Pangkalan Kuras Kabupaten Pelalawan. Dipilihnya lokasi penelitian ini, dengan alasan bahwa masyarakat daerah ini masih melaksanakan ritual tolak bala, sehingga fenomena yang dikaji ditemukan di kawasan ini. Data yang diperlukan terdiri dari data primer dan data sekunder. Data primer yang dikumpulkan

\footnotetext{
${ }^{30}$ Judistira K. Garna, Metode Penelitian Pendekatan Kualitatif (Bandung: Primico Akademika, 1999), 32; Lexy J. Moleong, Metodologi Penelitian Kualitatif (Bandung: Remaja Rosdakarya, 2000), 2-3.

${ }^{31}$ R. Bogdan \& S.J. Tylor, Kualitatif Dasar-dasar Penelitian (terjemahan) (Surabaya: Usaha Nasional, 1993), 4.
}

dalam penelitian ini terpusat pada fenomenafenomena yang berkaitan langsung dengan objek penelitian; yaitu Ritual Tolak Bala di Desa Betung Kecamatan Pangkalan Kuras Kabupaten Pelalawan, yang meliputi; proses pelaksanaan ritual tolak bala, media yang digunakan, orangorang yang terlibat dalam proses pelaksanaan, dan urgensi ritual tolak bala bagi masyarakat. Sedangkan data sekunder adalah data-data yang dipandang terkait dengan penelitian ini, dan dibatasi berdasarkan relevansi dengan pertanyaan penelitian yang kesemuanya dianalisis dari perspektif Sosiologi Agama dan Antropologi Agama.

Adapun teknik pengumpulan data yang digunakan adalah observasi, wawancara, dan dokumentasi. Untuk mendapatkan informasi yang diperlukan dalam penelitian ini, maka peneliti menentukan informan kunci (key informant) dengan kriteria: (1) Orang yang dapat memberikan informasi secara mendalam dan rinci tentang kebudayaan dan tradisi yang terdapat di Desa Betung Kecamatan Pangkalan Kuras Kabupaten Pelalawan. (2) Orang yang mampu memberikan informasi secara mendalam tentang Ritual Tolak Bala yang terdapat di Desa Betung Kecamatan Pangkalan Kuras Kabupaten Pelalawan.

Berdasarkan struktur sosial masyarakat Desa Betung Kecamatan Pangkalan Kuras Kabupaten Pelalawan, maka yang menjadi informan dalam penelitian ini berjumlah 20 orang. Untuk melihat kebenaran data dalam penelitian ini dilakukan cross checks data di antara informan-informan yang ditentukan di lapangan. Informan berasal dari berbagai kalangan yang terdapat dalam masyarakat, antara lain tokoh agama, tokoh masyarakat, dukun, panitia pelaksana, ninik mamak, pimpinan formal, dan tokoh adat.

Kegiatan analisis data dilakukan dilakukan sepanjang penelitian ini berlangsung. Adapun teknik analisis yang digunakan adalah analisis deskriptif. Analisis deskriptif (descriptive analysis) mengandung pengertian sebagai usaha untuk menyederhanakan dan sekaligus 
menjelaskan bagian dari keseluruhan data melalui langkah-langkah klasifikasi sehingga tersusun suatu rangkaian deskripsi yang sistematis dan akurat. Untuk mendapatkan informasi yang betulbetul akurat, maka dilakukan cek silang (cross check) melalui teknik triangulasi terhadap setiap informasi yang diperoleh, baik informasi yang diperoleh melalui wawancara mendalam (in depth interview) maupun informasi yang diperoleh melalui observasi.

\section{Profil Masyarakat Petalangan}

\section{a. Sejarah Petalangan}

Istilah Petalangan berasal dari kata "talang" yang ditambah imbuhan pe dan an. Kata "talang" memiliki beberapa arti, dalam Kamus Dewan disebutkan bahwa talang diartikan juga sebagai saluran air yang berasal dari buluh (bambu) pada cucuran atap rumah. Arti yang paling dekat yang dapat dikaitkan dengan Orang Petalangan adalah “dusun kecil dekat hutan”. Orang Talang juga disebut orang dusun atau orang "hulu", juga dianggap sebagai "orang yang rendah martabatnya". ${ }^{32}$ Pengertian Petalangan seperti yang dijelaskan tersebut juga dibenarkan oleh masyarakat Petalangan Desa Betung Kecamatan Pangkalan Kuras. ${ }^{33}$ Dengan demikian, Orang Petalangan atau Orang Talang secara umum dapat diartikan sebagai satu kelompok masyarakat yang hidup dengan pola pemukiman dusun-dusun kecil dekat hutan. Pola pemukiman seperti ini berkait erat dengan sistem mata pencarian hidup pokok mereka, yaitu berladang-kasang (shifting cultivation) di hutan kering dan berladang bencah di rawa dan tepi sungai, seperti halnya orang Iban di Kalimantan atau orang Badui di Banten.

\footnotetext{
${ }^{32}$ Kamus Dewan, Edisi Keempat, Cetakan Ketiga (Kuala Lumpur: Dewan Bahasa dan Pustaka, 2010), 1580.

${ }^{33}$ Dugang, "Sistem Kepercayaan dalam Pengobatan Tradisional (Studi Kasus Pada Komunitas Melayu Petalangan di Kabupaten Pelalawan)" (Skripsi: Universitas Riau, 2011), 38.
}

Menurut Tenas Effendy, orang Talang atau Petalangan termasuk salah satu puak "suku asli"34 di Riau yang tersebar di 12 kecamatan di Kabupaten Pelalawan. Pemukiman orang Petalangan sebagian besar berada di tepi hutan, dalam hutan, dan di pinggir Sungai Kampar beserta anak-anak sungainya, seperti Sungai Segati, Batang Nilo, Sungai Napuh, Sungai Telayang, Sungai Ransang, Sungai Panduk, dan Sungai Kerumutan. Konsep suku asli atau suku terasing atau Komunitas Adat Terpencil (KAT) digunakan oleh pemerintah untuk etnik yang terisolir. Istilah ini merujuk pada etnis asli yang "terisolir dan memiliki keterbatasan dalam berkomunikasi dengan masyarakat yang lebih modern, dan karenanya mereka terbelakang dan tertinggal dalam proses pembangunan ekonomi, politik, sosio-budaya, religi dan ideologi". ${ }^{35}$ Meskipun secara resmi orang Petalangan tidak dikategorikan sebagai suku terasing, namun mereka lebih berpotensi terpinggirkan, karena pada satu sisi mereka dianggap inferior, tapi di sisi lainnya tersisihkan dari wacana resmi marginalitas.

Meski sejarah Suku Petalangan tidak terungkap secara jelas, namun pandangan tentang Suku Petalangan terbagi dua. Pertama, mereka merupakan golongan Proto Melayu (Melayu Tua) yang datang ke wilayah ini sekitar 2500-1500 SM. Kedua, mereka berasal dari golongan Deutro Melayu (Melayu Muda) yang datang sekitar tahun 300 SM. $^{36}$ Ada berbagai versi pendapat tentang asal usul Orang Petalangan. Menurut Tenas Effendy, Orang Petalangan, khususnya yang berdiam di Kecamatan Pangkalan Kuras, percaya bahwa mereka adalah Orang Melayu yang

\footnotetext{
${ }^{34}$ Tenas Effendy, "Orang Talang dan Kebudayaannya", Makalah, 1998.

${ }^{35}$ Ashley M. Turner, "Cultural Survival, Identity and the Performing Arts of Kampar's Suku Petalangan”, BKI 153, no. 4 (1997): 648-71.

${ }^{36}$ Tenas Effendy, Sekilas tentang Orang Talang di Riau (Pekanbaru: Dewan Kesenian Riau, 1995); Sudirman Shomary, "Nyanyian Panjang Orang Talang di Riau: Suatu Kajian Kes" (Thesis: Universiti Kebangsaan Malaysia, 1998).
} 
berasal dari Johor. Mereka adalah keturunan dari Bujang Tan Domang yang bergelar Datuk Demang Serail yang merantau dari Johor dengan cara masuk dan memudiki sungai Kampar sampai ke Batang Nilo. ${ }^{37}$ Seterusnya, menurut Kulun (Penghulu Mudo Suku Pelabi dari Desa Sorek Dua), bahwa kedatangan Orang Petalangan ke Kabupaten Pelalawan, khususnya Pangkalan Kuras, tidaklah terjadi secara serempak, tetapi suku demi suku. Empat suku yang datang paling awal adalah Melayu Tua, Melayu Muda, Piliang Soni dan Pelabi, berasal dari Gunung Hijau (Gunung Merapi) di Agam, Minangkabau. Suku Pelabi adalah pecahan dari Suku Caniago dari Minangkabau. Manakala Suku Penyabungan adalah pendatang kemudian yang berasal dari Bonio-Koto Medan (Peranab, Indragiri Hulu). ${ }^{38}$ Sedangkan menurut Lasik (Monti Sutan Pebatinan Pematan dari Desa Batang Kulim), bahwa sebagian Orang Petalangan berasal dari Johor dan sebagian lain dari Minangkabau. ${ }^{39}$

\section{b. Ekonomi dan Mata Pencaharian}

Secara umum, Orang Petalangan di Desa Betung mata pencaharian utamanya adalah sebagai petani (padi, karet, dan sawit), berburu, mencari hasil hutan, nelayan, berdagang kecil-kecilan, buruh, dan ada juga yang menjadi pegawai negeri. Sampai sekitar tahun 1990, yaitu ketika sebagian besar hutanhutan di daerah Kabupaten Pelalawan mulai dibuka menjadi perkebunan-perkebunan besar kelapa sawit, Orang Petalangan masih hidup dari perladangan padi. Mata pencarian lain sebagai tambahan adalah berburu binatang, menangkap ikan, mencari madu lebah dan hasil-hasil hutan bukan-kayu, dan lain-lain.

\footnotetext{
${ }^{37}$ Tenas Effendy, Bujang Tan Domang: Sastra Lisan Orang Petalangan, cet. Ke-2 (Jakarta: Yayasan Obor Indonesia, 2008), 67-68.

${ }^{38}$ Kulun, Wawancara, 12 Februari 2016, Desa Sorek Dua.

${ }^{39}$ Lasik, Wawancara, 13 Februari 2016, Desa Batang Kulim.
}

Berladang dilakukan oleh suami istri sebagai satu kelompok kerja. Biasanya berladang ini dilakukan secara bekerjasama oleh tiga kelompok suami-istri yang suaminya adalah ber-pamoyan. Lazimnya mereka membuka ladang di tanah ulayat milik suku para istri tersebut.

Pada masa dahulu, Orang Petalangan umumnya amat terkait kepada hutan tanah ulayatnya, sehingga mereka nyaris tidak beranjak dari kawasannya. Di sanalah mereka membangun kampung, membuka kebun dan ladang serta menjaga rimba larangannya. Keterikatan orang Petalangan dengan hutan menyebabkan mereka sangat bergantung pada hasil hutan untuk memenuhi kebutuhan hidup dan membuka tanah perladangan. Dari hutan mereka mendapatkan berbagai jenis getah kayu seperti getah balam merah, getah jelutung, getah sondeh, damar dan gaharu, buah-buahan rimba, hewan buruan, dan lainlain. Dari ketersediaan hutan (rimba) pula orang Petalangan membuka hutan untuk dijadikan tempat berladang yakni berladang padi.

Bagi masyarakat Petalangan, berladang padi bukan saja sebagai sumber penghasilan tetapi yang lebih urgen (penting) lagi ialah berladang sebagai lambang "tanggung jawab orang tua terhadap anak dan keluarganya". Berladang padi dilakukan dengan dua cara, yakni "Ladang Kasang”, berladang di tanah pematang (daratan) disebut juga dengan "Ladang Tugal", dan "Ladang Bencah" di tanah rawa, disebut juga "Ladang Tabur".

Sejak tahun 2005 dan marak pembukaan kebun sawit di kawasan masyarakat Petalangan, masyarakat Desa Betung mulai menjalin mitra dengan PT. Musi Mas dalam bentuk Koperasi Kredit Primer Anggota (KKPA) seluas 354 Ha yang dibagi dalam 2 tahap, yaitu $164 \mathrm{Ha}$ tahap pertama dan 190 Ha tahap kedua yang telah dikonversikan kepada masyarakat. Selain itu, pada tahun 2009 masyarakat juga 
menjalin mitra dengan PT. Surya Bratasena Plantation dalam bentuk KKPA seluas $350 \mathrm{Ha}$. Dengan masuknya perkebunan sawit di daerah masyarakat Petalangan dan adanya pola KKPA, maka mata pencaharian utama mereka beralih dari petani padi ke petani sawit.

\section{c. Agama dan Kepercayaan}

Agama dan kepercayaan merupakan suatu yang asas dalam kehidupan manusia. Setiap masyarakat di dunia ini menganut satu agama dan kepercayaan tertentu. Dari berbagai hasil penelitian ditemukan bahwa tidak ada masyarakat di dunia ini yang tidak memiliki agama, baik dalam masyarakat yang masih terbelakang maupun yang sudah maju. Sistem agama dan kepercayaan merupakan aspek kebudayaan yang terjaring luas dalam masyarakat. Melalui agama dan kepercayaan inilah manusia melakukan hubungan dengan yang gaib (Tuhan) yang dipandang mempunyai pengaruh dalam kehidupan manusia.

Orang Melayu, demikian juga Orang Petalangan, membedakan antara agama dan kepercayaan. Dalam pandangan mereka yang dimaksud dengan agama hanyalah agamaagama besar yang diakui oleh pemerintah - seperti Islam, Kristen, Khatolik, Hindu, Buddha, dan Konghucu - sedangkan kepercayaan adalah keyakinan kepada kekuatan yang dimiliki makhluk halus (jin, hantu, jembalang, sikodi, dan lain-lain). Kepercayaan juga mencakup upacaraupacara yang lahir dari kebiasaan-kebiasaan lama, seperti menyemah kampung, mati tanah, membuang ancak, dan sebagainya. Penggunaan kata agama dan kepercayaan dari segi ini tidak terlalu jauh menyimpang dari penggunaannya dalam ilmu sosial, karena agama (religion) lebih ditujukan kepada sistem kepercayaan yang teratur atau berorganisasi, sedangkan kepercayaan (beliefs) ditujukan kepada fenomena yang tidak memiliki ciri-ciri yang berorganisasi atau sistem. ${ }^{40}$

Masyarakat Petalangan seluruhnya menganut agama Islam, mereka sangat tersinggung apabila disebut orang yang tidak beragama. Memang terdapat penganut agama lain, namun mereka berasal dari masyarakat pendatang yang bekerja di perkebunan sawit yang terdapat di kawasan masyarakat Petalangan. Di samping agama, sisa-sisa kepercayaan lama (animisme dan dinamisme serta pengaruh Hindu dan Budha) masih terlihat mewarnai beberapa unsur kebudayaan masyarakat Petalangan. Pengaruh ini nampak antara lain dalam upacara pengobatan yang disebut "belian", "bedukun", "membuang ancah", "menyemah", "tolak bala", dan lain-lain. Demikian pula dalam upacara mendirikan bangunan yang disebut upacara "meramu", "menetau tanah", "menegakkan rumah", serta dalam upacara mengambil madu lebah di pohon Sialang yang disebut upacara "menumbai".

Kuatnya pengaruh kepercayaan amat nyata dalam kehidupan sehari-hari masyarakat Petalangan. Hampir seluruh kegiatan Orang Petalangan menggunakan mantra dan meminta bantuan kepada kekuatan gaib yang terdapat di alam sekitar tempat tinggal mereka. Hal ini tentu saja ada kaitannya dengan pandangan masyarakat Petalangan terhadap alam sekitar. Masyarakat Petalangan menganggap alam sekitar sebagai bagian dari diri dan hidup mereka. Bagi mereka, alam bukan hanya sebagai tempat hidup untuk mencari nafkah, tetapi juga menjadi sumber nilai budaya.

\section{Pemahaman Masyarakat Petalangan Tentang Ritual Tolak Bala}

Masyarakat Petalangan, sebelum mengenal dan menganut Islam, mereka memiliki kepercayaan yang bersifat animisme dan dinamisme. Kehidupan masyarakat Petalangan yang berada di kawasan

\footnotetext{
${ }^{40}$ Mohd. Taib Osman (ed.), 147.
} 
pinggiran atau dalam hutan membuat kepercayaan ini begitu mengakar dalam kehidupan mereka. Kehidupan yang bergantung dengan alam sekitar dan belum dikenalnya teknologi, mengharuskan mereka menjalin hubungan yang harmonis dengan alam sekitar. Dalam pandangan mereka, lingkungan alam dihuni atau dikuasai oleh makhlus gaib atau makhluk halus. Mereka percaya bahwa makhluk halus tersebut ada yang baik dan ada yang jahat. Oleh karena itu, makhluk halus yang baik dijadikan sahabat (disebut akuan), dan yang jahat harus dibujuk agar jangan mengganggu kehidupan masyarakat. Untuk itu, mereka melakukan berbagai upacara agar yang baik tetap menjadi sahabat, dan yang jahat tidak mengganggu atau mendatangkan bencana. Pemahaman ini didasarkan atas kepercayaan bahwa makhluk halus tersebut dapat mendatangkan kebahagiaan dan dapat pula mendatangkan bencana. Oleh karena itu, mereka berusaha untuk menjaga "hubungan baik" dengan makhluk-makhluk halus tersebut dengan cara antara lain melakukan upacara tertentu atau dengan mematuhi ketentuan "pantang larang" yang ditetapkan oleh adat. ${ }^{41}$

Dalam Antropologi, upacara ritual dikenal dengan istilah ritus. Ritus dilakukan dengan berbagai tujuan, ada untuk mendapatkan berkah atau rezeki yang banyak dari suatu pekerjaan, seperti upacara sakral ketika akan turun ke sawah; ada untuk menolak bahaya yang telah atau diperkirakan akan datang; ada upacara mengobati penyakit (rites of healing); ada upacara karena perubahan atau siklus dalam kehidupan manusia, seperti pernikahan, mulai kehamilan, kelahiran (rites of passage, cycles rites); dan sebaginya. ${ }^{42}$

Masyarakat Petalangan mengadakan ritual tolak bala sebagai antisipasi dari beberapa penyakit atau bencana yang diakibatkan oleh gangguan

${ }^{41}$ Tenas Effendy, Adat Istiadat dan Upacara Perkawinan di Bekas Kerajaan Pelalawan (Pekanbaru: Lembaga Adat Daerah Riau, 1998), 45.

${ }^{42}$ Edward Norbeck, Religion and Human Life (New York: Holt, Rinehart and Winston Inc., 1974), 40-54. makhluk halus. Untuk itu, mereka mengadakan sesajian kepala kerbau untuk meminta bantuan agar makhluk halus tidak mengganggu. Selain penggunaan kepala kerbau sebagai sesajian, mereka juga memasang tangkal di rumah dan juga di perbatasan kampung sebagai pelindung kampung. Perlindungan menggunakan tangkal ini didasari atas adanya masyarakat Petalangan yang menggunakan akuan untuk berbuat jahat kepada orang lain. Agar perbuatan jahat tadi tidak masuk ke rumah-rumah masyarakat Petalangan, maka seorang dukun memberikan tangkal perlindungan untuk mengelabui akuan sehingga rumah yang menjadi sasaran "tidak terlihat". Sedangkan tangkal di perbatasan kampung bertujuan untuk mengelabui perbuatan jahat manusia yang memiliki akuan agar kampung yang menjadi sasaran "tidak terlihat".

Setelah masyarakat Petalangan masuk Islam, maka berubahlah konsep dasar tolak bala dan ritual ini diisi dengan unsur-unsur Islam. Perbedaan tersebut dapat dilihat pada tabel berikut ini:

Tabel 1: Ritual Tolak Bala Pada Masyarakat Petalangan Sebelum dan Setelah Memeluk Islam $^{43}$

\begin{tabular}{|l|l|l|}
\hline No. & $\begin{array}{l}\text { Sebelum Memeluk } \\
\text { Islam }\end{array}$ & $\begin{array}{l}\text { Setelah Memeluk } \\
\text { Islam }\end{array}$ \\
\hline 1. & $\begin{array}{l}\text { Kepala kerbau } \\
\text { ditanam di tempat- } \\
\text { tempat keramat } \\
\text { atau perbatasan } \\
\text { kampung }\end{array}$ & $\begin{array}{l}\text { Kepala kerbau } \\
\text { dihidangkan atau } \\
\text { dipersembahkan untuk } \\
\text { makhluk gaib diikuti } \\
\text { dengan kenduri tolak } \\
\text { bala }\end{array}$ \\
\hline 2. & $\begin{array}{l}\text { Pelaksanaan ritual } \\
\text { tolak bala dengan } \\
\text { tujuan meminta } \\
\text { bantuan makhluk } \\
\text { halus untuk } \\
\text { memelihara } \\
\text { kampung dan } \\
\text { melindungi } \\
\text { masyarakat } \\
\text { Petalangan }\end{array}$ & $\begin{array}{l}\text { Pelaksanaan ritual tolak } \\
\text { bala tidak hanya } \\
\text { bertujuan meminta } \\
\text { bantuan kepada } \\
\text { makhluk halus, tetapi } \\
\text { juga meminta kepada } \\
\text { Allah untuk melindungi } \\
\text { kampung dan } \\
\text { masyarakat Petalangan }\end{array}$ \\
\hline
\end{tabular}

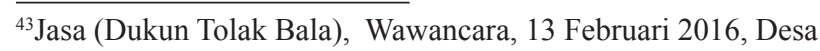
Betung. 


\begin{tabular}{|c|c|c|}
\hline 3. & $\begin{array}{l}\text { Pelaksanaan ritual } \\
\text { tolak bala } \\
\text { berdasarkan kepada } \\
\text { banyaknya penyakit } \\
\text { akibat dari } \\
\text { kejahatan makhluk } \\
\text { halus }\end{array}$ & $\begin{array}{l}\text { Ritual tolak bala } \\
\text { dilakukan sebagai } \\
\text { tradisi yang diwariskan } \\
\text { oleh leluhur mereka } \\
\text { agar tidak terkena } \\
\text { penyakit akibat } \\
\text { kejahatan dari makhluk } \\
\text { halus }\end{array}$ \\
\hline
\end{tabular}

Tabel di atas menunjukkan adanya perubahan pemahaman masyarakat Petalangan terhadap ritual tolak bala, di mana sebelum mereka memeluk Islam, ritual ini sepenuhnya bernuansa animisme dan dinamisme. Sedangkan setelah mereka memeluk Islam, ritual ini diisi dengan unsur-unsur Islam, seperti doa yang dilakukan dalam acara kenduri. Demikian juga, jika sebelumnya kekuatan tertinggi berada pada makhluk halus, namun setelah memeluk Islam mereka meminta bantuan kepada Allah. Meskipun harus diakui pemahaman seperti ini tentu saja tidak sepenuhnya Islami, dengan kata lain masih mengandung hal-hal yang bertentangan dengan ajaran atau akidah Islam.

Fenomena di atas menunjukkan tentang adanya pertautan antara agama dan realitas budaya yang memberikan arti bahwa perkembangan agama dalam suatu masyarakat, baik dalam wacana dan praktiknya, menunjukkan adanya unsur konstruksi manusia. Walaupun tentu pernyataan ini tidak berarti bahwa agama adalah ciptaan manusia, melainkan hubungan yang tidak bisa dielakkan antara konstruksi Tuhan, seperti yang tercermin dalam kitab-kitab suci, dan konstruksi manusia, terjemahan dan interpretasi dari nilai-nilai suci agama yang direpresentasikan pada praktik ritual keagamaan. Pada saat manusia melakukan interpretasi terhadap ajaran agama, maka mereka dipengaruhi oleh lingkungan dan nilai-nilai budaya yang telah melekat di dalam dirinya. Hal ini dapat menjelaskan kenapa interpretasi terhadap ajaran agama berbeda dari satu masyarakat ke masyarakat lainnya.

\section{Pelaksanaan Ritual Tolak Bala}

\section{a. Persiapan}

Persiapan pelaksanaan ritual tolak bala dimulai dengan rapat bersama yang dipimpin oleh pimpinan masing-masing kepala suku masyarakat Petalangan yang disebut Ninik Mamak. ${ }^{44}$ Dalam rapat tersebut dirundingkan tentang pelaksanaan tolak bala, mencari titik temu jika terdapat perbedaan untuk mencapai kesepakatan. Persiapan ini terbentuk melalui kerjasama ninik mamak untuk mengumpulkan anak kemenakan masing-masing (se-suku), agar mengikuti rapat dengan agenda persiapan pelaksanaan ritual tolak bala (pengobatan kampung). Rapat persiapan ini bertujuan agar pelaksanaan ritual ini berjalan dengan baik dan dapat dipertanggungjawabkan, serta pembetukan panitia pelaksana. ${ }^{45}$

Menurut Kutar, ${ }^{46}$ tolak bala yang dilaksanakan setiap tahunnya perlu persiapan yang matang karena melibatkan banyak orang, dan bukan untuk kepentingan para ninik mamak. Oleh karena itu, ritual ini harus dilaksanakan secara gotong royong, baik dalam bentuk tenaga maupun materi (uang). Menurut Jiun, ${ }^{47}$ panitia pelaksana sudah menetapkan besaran sumbangan setiap kepala keluarga. Hal serupa juga dinyatakan oleh Nursahabat, ${ }^{48}$ meskipun begitu warga tetap boleh menyumbang lebih besar atau kurang dari yang telah ditetapkan oleh panitia. Kaum ibu juga terlibat aktif dalam pelaksanaan ritual ini, satu atau dua hari menjelang dilaksanakannya kenduri tolak bala,

\footnotetext{
${ }^{44}$ Ninik mamak merupakan pimpinan suku yang dipilih secara musyawarah anggota keluarga laki-laki. Ninik mamak berperan menyelesaikan berbagai macam permasalahan yang terjadi, baik dalam suku maupun antar suku. Oleh karena itu, ninik mamak harus memiliki pengetahuan yang mendalam tentang adat istiadat.

${ }^{45}$ Kundang (Ninik Mamak), Wawancara, 13 Februari 2016, Desa Betung.

${ }^{46}$ Kutar (Ninik Mamak), Wawancara, 14 Februari 2016, Desa Betung.

${ }^{47}$ Jiun (Warga Masyarakat), Wawancara, 13 Februari 2016, Desa Betung.

${ }^{48}$ Nursahabat (Panitia Pelaksana), Wawancara, 14 Februari 2016, Desa Betung.
} 
mereka secara bergotong royong memasak dan membawa bumbu-bumbu dapur dari rumah masing-masing. ${ }^{49}$

Besar atau kecilnya kenduri tolak bala dapat dilihat dari seberapa banyak kambing yang dipotong. Namun, sebenarnya kenduri tolak bala dianggap besar apabila memotong sapi atau kerbau. Sedangkan meriah atau tidaknya dapat dilihat dari seberapa banyak ayam yang dipotong. Kambing merupakan menu utama yang dijadikan lauk pauk dalam acara kenduri tersebut. ${ }^{50}$

\section{b. Waktu dan Tempat Pelaksanaan}

Setelah mengadakan musyawarah, maka ninik mamak dan anak kemenakan menyepakati dan menetapkan beberapa hal, antara lain berkaitan dengan waktu dan tempat pelaksanaan. Pelaksanaan tolak bala dilakukan setiap tahunnya pada tanggal 15 Februari. Tidak ada penjelasan tentang mengapa pelaksanaan tolak bala dilakukan pada tanggal tersebut. Menurut Jasa, hal ini dilakukan sebagai warisan nenek moyang, dan "wajib" dilaksanakan setiap tahun, jika tidak dilaksanakan, maka itu dianggap hutang dan berakibat kampung tersebut ditimpa bala. ${ }^{51}$ Berkaitan dengan waktu pelaksanaan, menurut Jami'aturrahman, tolak bala tidak mutlak harus dilakukan pada tanggal 15 Februari, boleh saja dilaksanakan tanggal 13 atau 14 Februari, yang penting tidak boleh melewati tanggal 15 Februari, apalagi melampaui bulan Februari. Jika dilaksanakan melewati tanggal 15 Februari, dipercayai akan membahayakan masyarakat Petalangan, seperti gangguan makhluk halus, kerasukan jin, bencana alam, dan sebagainya. ${ }^{52}$

\footnotetext{
${ }^{49}$ Observasi, 15 Februari 2016, Desa Betung.

${ }^{50}$ Nursahabat (Panitia Pelaksana) dan Muklis (Warga Masyarakat), Wawancara, 14 Februari 2016, Desa Betung.

${ }^{51}$ Jasa (Dukun Tolak Bala), Wawancara, 13 Februari 2016, Desa Betung.

${ }^{52}$ Jami'aturrahman (Ketua Panitia Pelaksana), Wawancara, 14 Februari 2016, Desa Betung.
}

Selain menetapkan tanggal, hari, dan bulan pelaksanaan tolak bala, kesepakatan musyawarah juga menetapkan jam atau waktu acara kenduri dilaksanakan. Waktu pelaksanaan biasanya malam hari, karena pada malam hari masyarakat Petalangan tidak ada kesibukan atau sudah tidak beraktivitas seperti di siang hari, sehingga semua warga masyarakat bisa hadir dalam acara tersebut. Sedangkan waktu pelaksanaan biasanya dilakukan setelah shalat Maghrib.

Menurut Kundang, tempat pelaksanaan kenduri tolak bala terbagi dua, yaitu di rumah dan di perbatasan kampung. Rumah yang dipilih sebagai tempat pelaksanaan kenduri biasanya rumah ninik mamak. Rumah merupakan tempat pelaksanaan kenduri, sedangkan di perbatasan kampung dilakukan pemasangan tangkal perlindungan. Pada saat pemasangan tangkal tidak ada acara mendoa sebagaimana dilakukan oleh nenek moyang mereka masa lalu, karena doa yang dibaca sama dengan yang dibaca pada acara kenduri tolak bala di rumah. ${ }^{53}$ Pendapat serupa juga dikemukakan oleh Jasa, bahwa tempat pelaksanaan tolak bala harus berbeda, yaitu mendoa secara bersama-sama dilakukan di rumah, sedangkan pemasangan tangkal yang berfungsi sebagai pelindung dari berbagai macam gangguan makhluk halus dilakukan di perbatasan kampung. ${ }^{54}$

\section{c. Media yang Digunakan}

Media merupakan sesuatu yang penting dalam ritual tolak bala. Setiap media merupakan simbol yang memiliki makna tertentu. Dengan menggunakan media tertentu, suatu ritual bisa mencapai tujuan yang diinginkan. Tanpa media, suatu ritual tidak mungkin dilaksanakan. Menurut

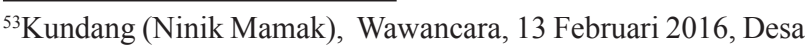
Betung.

${ }^{54}$ Jasa (Dukun Tolak Bala), Wawancara, 13 Februari 2016, Desa Betung.
} 
Parsudi Suparlan, makna dari suatu simbol mewakili suatu pengertian abstrak, luas, dan bersifat universal. ${ }^{55}$ Ada beberapa media yang digunakan dalam pelaksanaan ritual tolak bala yang melambangkan makna dari simbol-simbol persembahan, yaitu: (1) Kayu gaharu, berfungsi untuk mengundang roh para leluhur dan juga makhluk halus lainnya. (2) Pulut kuning, sebagai persembahan kepada makhluk halus untuk menjadi santapannya yang diibaratkan seperti manusia memakan nasi. (3) Hewan persembahan (berupa kambing, sapi atau kerbau), merupakan sesajian untuk makhluk halus, dalam hal ini yang dihidangkan meliputi; kepala, isi perut, dan daging. Pada hakikatnya semua bagian tersebut dianggap sebagai satu ekor hewan yang dipersembahkan untuk roh para leluhur dan makhluk halus. (4) Tepung tawar, dilakukan pada rumah dengan maksud agar makhluk halus sulit mengganggu atau masuk ke rumah tersebut. Dengan demikian, tepung tawar merupakan simbol dari pelindung rumah. Adapun bahan-bahan yang digunakan untuk tepung tawar adalah; sebagai alat untuk tepung tawar diambil dari tanaman setawe, sedingin, ati-ati, dan adau uso. Sedangkan yang menjadi alat percikan tepung tawar adalah limau (jeruk) mentimum dan kasai, jika digabungkan menjadi limau kasai. Kasai terbuat dari beras yang digiling halus dan diberi warna putih, merah, dan kuning. Warna-warna tersebut memiliki makna, putih melambangkan tulang, merah melambangkan daging, dan kuning melambangkan pelindung. Jadi, hakikat dari warna tersebut adalah melindungi dari berbagai bahaya. (5) Kain kencono dan titian umban (bahan untuk membuat tangkal), kain kencono merupakan peralatan yang terbuat dari kain yang terdiri dari berbagai warna, yaitu warna merah sebagai

${ }^{55}$ Parsudi Suparlan, Kebudayaan, Masyarakat dan Agama: Agama sebagai Sasaran Penelitian Antropologi (Jakarta: Depag RI., 1981), 6. simbol masyarakat, putih sebagai simbol pegawai, hitam sebagai simbol dubalang, dan kuning sebagai simbol kerajaan. Titian umban merupakan peralatan yang digabungkan pada benang kencono yang terbuat dari daun kepau atau pucuk kelapa. Kain kencono dan titian umban berfungsi sebagai pelindung rumah. (6) Limau (jeruk) nipis, sebagai simbol suci yang mampu membersihkan, menanggalkan, dan menghilangkan penyakit. Dalam ritual tolak bala, limau nipis sebagai simbol menghalau penyakit yang melekat di rumah atau pada diri manusia. ${ }^{56}$

\section{d. Tata Cara Pelaksanaan}

Pelaksanaan ritual tolak bala melalui beberapa tahapan, yaitu: (1) Memotong limau; sebelum limau dipotong terlebih dahulu dimantrai oleh dukun. Tidak begitu jelas seperti apa mantra yang dibaca oleh dukun, hanya saja yang terdengar adalah bacaan Basmalah. Mantra merupakan contoh sinkretisme yang par excellence. Ia bukan saja mengandung unsur lokal yang asli (animisme), tetapi juga unsur Hindu dan Islam. Kepercayaan kepada hantu, semangat, dan penunggu merupakan kepercayaan asli orang Petalangan, yaitu sejak munculnya animisme sebagai kepercayaan mereka. Kemudian datang pengaruh Hindu, konsep dewa pula diambil sebagai salah satu kekuatan gaib. Setelah datang Islam, mereka menggabungkan kepercayaan Islam dengan kepercayaan yang telah ada. Menurut UU. Hamidy, memasukkan basmalah pada permulaan mantra dan diakhiri dengan sebutan "La ilaha illallah, Muhammadar Rasulullah", adalah bentuk dari Islamisasi sastra Melayu, khususnya dalam bidang mantra. ${ }^{57}$ Sebelum limau dipotong terlebih dahulu disediakan mangkuk yang berisi air sebagai tempat

\footnotetext{
${ }^{56}$ Jasa (Dukun Tolak Bala), Wawancara, 13 Februari 2016, Desa Betung.

UU. Hamidy, Islam dan Masyarakat Melayu di Riau (Pekanbaru: UIR Press, 1999), 121.
} 
untuk menjatuhkan limau yang dipotong oleh dukun. Pemotongan limau merupakan tanda dimulainya pelaksanaan ritual tolak bala, di mana mantra yang dibaca sewaktu memotong limau bertujuan untuk memanggil roh para leluhur dan makhluk gaib agar memberi perlindungan kepada masyarakat Petalangan Desa Betung. ${ }^{58}$ (2) Kenduri Tolak Bala; dalam acara kenduri tolak bala masyarakat Petalangan membaca Surat Yasin secara bersama-sama dan ditutup dengan membaca doa tolak bala. Sebelum pembacaan Surat Yasin dan doa tolak bala, terlebih dahulu disiapkan hidangan persembahan (kepala kerbau/sapi/kambing), air limau, dan tangkal. Barang-barang persembahan tersebut diletakkan tepat di tengah-tengah rumah dan dikelilingi masyarakat yang melaksanakan kenduri. ${ }^{59}$ Maksud dilaksanakan kenduri tersebut adalah memohon kepada Allah agar melindungi masyarakat Petalangan dan kampung mereka terhindar dari berbagai macam bahaya. ${ }^{60}$ (3) Pemakaian Tangkal Tolak Bala; setelah acara kenduri tolak bala selesai, masyarakat Petalangan membawa pulang air limau dan tangkal. Jika ada salah satu warga masyarakat yang tidak hadir dalam acara tersebut, maka air limau dan tangkal dititipkan kepada tetangganya. Sedangkan ustadz dan dukun membawa air limau dan tangkal tersebut ke perbatasan kampung. Air limau yang dibawa pulang oleh warga digunakan dengan cara diusapusap di bagian muka, tangan, dan kaki. Hal ini dilakukan oleh seluruh anggota keluarga yang dilaksanakan pada malam hari. Air limau tersebut juga dipercikkan ke setiap dinding rumah dan diikuti dengan memasang tangkal pada angin-angin pintu depan yang dilakukan pada siang hari. Menurut Jasa, air limau

\footnotetext{
${ }^{58}$ Observasi, 15 Februari 2016, Desa Betung.

${ }^{59} \mathrm{Ibid}$.

${ }^{60}$ Bahrum (tokoh agama), Wawancara, 14 Februari 2016, Desa Betung.
}

nipis memiliki khasiat untuk membuang sial pada diri setiap orang, seperti sakit-sakitan, sering tertimpa masalah, dan sebagainya. Sedangkan air limau yang dipercikkan ke dinding rumah dan pemasangan tangkal bertujuan untuk melindungi penghuni rumah dari kejahatan makhluk halus. ${ }^{61}$ Pandangan serupa juga dikemukakan oleh Kumbi ${ }^{62}$ dan Kemel. ${ }^{63}$ Maka tidak heran jika di rumah masyarakat ditemukan beberapa buah tangkal, karena mereka memasang tangkal yang baru dan tangkal yang lama tidak dibuang. Sedangkan tangkal yang dipasang di perbatasan kampung dibuat khusus untuk melindungi kampung. Tangkal tersebut digantung dengan menggunakan kayu khusus, yaitu kayu ibu-ibu. Menurut Kumbi, kayu ibu$i b u$ dipilih untuk menggantungkan tangkal karena dipercayai merupakan kayu yang paling tua dibandingkan kayu lainnya, sebab itulah disebut kayu ibu-ibu. ${ }^{64}$

\section{Urgensi Ritual Tolak Bala Bagi Masyarakat Petalangan}

Seperti sudah dijelaskan sebelumnya bahwa ritual tolak bala dilaksanakan secara rutin setiap tahunnya oleh masyarakat Petalangan. Ada beberapa alasan yang menjelaskan mengapa ritual ini tetap dilaksanakan oleh masyarakat Petalangan dan masih bertahan meskipun mereka sudah bersentuhan dengan berbagai budaya (culture contact) lain, yaitu:

\section{a. Pewarisan Tradisi}

Masyarakat Petalangan amat kaya dengan tradisi dan ritual yang masih tetap dipertahankan serta diwariskan secara turun temurun. Dugang mengatakan bahwa

\footnotetext{
${ }^{61}$ Jasa (Dukun Tolak Bala), Wawancara, 13 Februari 2016, Desa Betung.

${ }^{62}$ Kumbi (Dukun Tolak Bala), Wawancara, 15 Februari 2016, Desa Betung.

${ }^{63} \mathrm{Kemel}$ (warga masyarakat), Wawancara, 16 Februari 2016, Desa Betung.

${ }^{64}$ Kumbi (Dukun Tolak Bala), Wawancara, 15 Februari 2016, Desa Betung.
} 
masyarakat Petalangan telah mengenal ritual tolak bala sejak dahulu kala dan terus dilaksanakan sebagai upaya melestarikan tradisi nenek moyang mereka. ${ }^{65}$ Ninik mamak berperan penting dalam menjaga berbagai tradisi yang dimiliki masyarakat Petalangan. Bagi masyarakat Petalangan, melaksanakan ritual tolak bala setiap tahunnya dianggap sebagai "kewajiban" yang harus ditunaikan, karena hal serupa telah dilaksanakan oleh nenek moyang mereka.

\section{b. Perlindungan dan Menolak Bencana}

Pelaksanaan ritual tolakbalajugamerupakan pemenuhan “janji atau kesepakatan” yang sudah dibuat oleh nenek moyang mereka dengan makhluk gaib. Kesepakatan tersebut berisikan saling menjaga dan tidak saling mengganggu. Sebagai realisasi dari janji tersebut, masyarakat Petalangan memberikan persembahan berupa kepala kerbau atau sapi atau kambing, dan makhluk halus menjaga atau melindungi serta tidak mengganggu warga masyarakat. Masyarakat mempercayai jika hal ini dilanggar (ritual tidak dilaksanakan), maka akan terjadi berbagai macam gangguan dari makhluk halus. ${ }^{66}$

\section{c. Membangun Solidaritas Sosial Masyarakat}

Pelaksanaan ritual tolak bala memerlukan dukungan dan keterlibatan seluruh anggota masyarakat. Kegiatan ini tidak bisa dilaksanakan hanya oleh sekelompok warga masyarakat saja, mengingat kegiatan ini memerlukan banyak tenaga manusia dan juga dana. Di samping itu, kegiatan ini juga memerlukan berbagai keahlian agar tujuan yang diharapkan dapat tercapai. Oleh karena

\footnotetext{
${ }^{65}$ Dugang (tokoh masyarakat), wawancara, 14 Februari 2016, Desa Betung.

${ }^{66} J a s a$ (Dukun Tolak Bala), Kumbia (Dukun Tolak Bala), Kemel (warga masyarakat), Agus (warga masyarakat), Kolek (warga masyarakat), Muklis (warga masyarakat), Jami'aturrahman (Ketua Panitia Pelaksana), Wawancara, 13 - 16 Februari 2016, Desa Betung.
}

itu, kegiatan yang dilaksanakan setiap tahun menunjukkan bentuk solidaritas sosial di kalangan masyarakat Petalangan. Mereka menyumbangkan apa saja sesuai dengan kemampuan, baik tenaga maupun uang. Hal ini terlihat dengan jelas dari ramainya warga masyarakat yang mengikuti atau hadir dalam kegiatan tersebut. Mereka hadir atas kesadaran sendiri dan bukan paksaan, baik dari ninik mamak maupun panitia pelaksana. Solidaritas sosial yang ditunjukkan oleh masyarakat Petalangan dapat disebut sebagai solidaritas sosial mekanik. Durkheim seperti yang dikutip Soerjono Soekanto menjelaskan bahwa solidaritas mekanik didasarkan pada suatu "kesadaran kolektif" (collective consciousness/conscience), yang menunjuk pada "totalitas kepercayaan-kepercayaan dan sentimen-sentimen bersama yang rata-rata ada pada warga masyarakat yang sama. Itu merupakan suatu solidaritas yang tergantung pada individu-individu yang memiliki sifatsifat yang sama dan menganut kepercayaan dan pola normatif yang sama pula. ${ }^{67}$

\section{Ritual Tolak Bala dan Keberagamaan Masyarakat Petalangan}

Masyarakat Petalangan seluruhnya menganut agama Islam, dan mereka tersinggung apabila dikatakan sebagai bukan seorang muslim, meskipun harus diakui banyak praktik yang dilakukan masyarakat Petalangan yang berbau animisme dan dinamisme. Di samping itu, sebagian dari masyarakat Petalangan belum menjalankan ajaran Islam sepenuhnya. ${ }^{68}$ Secara sosiologis, sebagian besar mereka dapat

\footnotetext{
${ }^{67}$ Soerjono Soekanto, Emile Durkheim: Aturan-aturan Metode Sosiologis (Jakarta: Rajawali Press, 1985), 4-9.

${ }^{68}$ Observasi, 12-17 Februari 2016. Desa Betung. Fenomena ini juga dikemukakan oleh Yoonhee Kang dalam penelitiannya. Lihat, Yoonhe Kang, Untaian Kata Leluhur: Marjinalitas, Emosi dan Kuasa Kata-kata Magi di Kalangan Orang Petalangan Riau (terjemahan) (Pekanbaru: Pusat Penelitian Kebudayaan dan Kemasyarakatan Universitas Riau, 2005), 30-31.
} 
dikatakan sebagai Islam nominal. ${ }^{69}$ Bertahannya kepercayaan tersebut dikarenakan masyarakat Petalangan memiliki hubungan psikologi yang kuat dengan alam sekitar. Mereka mempercayai bahwa alam ini dikuasai oleh makhluk-makhluk halus yang mungkin berkarakter baik dan juga jahat. Oleh karena itu, menjaga hubungan yang harmonis dengan makhluk-makhluk halus tersebut merupakan cara untuk memperoleh kedamaian dan ketenteraman dalam menjalankan kehidupan. Berpijak dari pandangan inilah munculnya berbagai macam ritual yang dibuat oleh masyarakat dengan tujuan tertentu. Fenomena ini menjelaskan tentang munculnya ritual karena adanya rasa takut manusia terhadap kekuatan tertentu yang menguasai alam.

Dalam praktiknya, ritual tolak bala mencampur unsur Islam, Hindu, animisme, dan dinamisme. Hal ini terlihat dengan jelas dari adanya persembahan dan pembacaan mantra yang ditujukan untuk mendapat bantuan dari makhluk halus. Ismail Yakub menjelaskan tentang beberapa unsur kepercayaan Hindu yang masih ditemukan di sebagian masyarakat Islam Indonesia, antara lain: (1) memuja arwah nenek moyang, (2) mantra dukun-dukun dengan memuja hantu dan dewadewa, (3) membakar kemenyan di dalam dupa, dan (4) menabur bunga di simpang-simpang jalan. ${ }^{70}$ Perilaku ini tentu saja bertentangan dengan apa yang diajarkan oleh Islam melalui al-Qur'an dan Sunnah. Dalam Islam, manusia

\footnotetext{
${ }^{69}$ Jalaluddin Rakhmat menyebutkan paling tidak ada lima cara dalam mendefinisikan umat Islam Indonesia, yaitu: (1) umat Islam didefinisikan sebagai himpunan orang yang menyatakan dirinya sebagai pemeluk agama Islam, (2) umat Islam didefinisikan sebagai himpunan orang yang sudah menjalankan ajaran-ajaran Islam, seperti shalat, zakat, dan sebagainya, (3) umat Islam didefinisikan sebagai himpunan orang yang memiliki pengetahuan yang memadai atau lebih dari itu tentang ajaranajaran Islam, (4) umat Islam didefinisikan sebagai himpunan orang yang berusaha mengatur perilakunya di tengah-tengah masyarakat sesuai dengan ajaran Islam, dan (5) umat Islam didefinisikan sebagai himpunan orang yang terlibat secara ideologis dengan ajaran Islam. Lihat Jalaluddin Rakhmat, "Islam di Indonesia: Masalah Definisi", dalam Islam di Indonesia: Suatu Ikhtiar Mengaca Diri, ed. M. Amien Rais (Jakarta: Sri Gunting, 1996), 37-58.

${ }^{70}$ Ismail Yakub, Sejarah Islam di Indonesia (Jakarta: Proyek Pengadaan Bahan Dakwah Depag RI, 1972), 63.
}

tidak boleh meminta bantuan kepada selain Allah, apalagi melakukan ritual yang diikuti dengan persembahan dan pembuatan tangkal. ${ }^{71}$

Seperti yang sudah disebutkan sebelumnya bahwa salah satu langkah islamisasi sastra (khususnya mantra) dalam budaya Melayu - hal ini juga berlaku pada masyarakat Petalangan - adalah dengan cara memasukkan katakata yang berasal dari ajaran Islam, seperti bismillahirrahmanirrahim, assalamu'alaikum, berkat la ilahaillallah muhammadar rasulullah, dan beberapa kata lainnya. Namun, jika ditinjau dari segi isinya, maka terlihat dengan jelas bahwa kandungannya masih kental dengan nuansa-nuansa animisme dan Hinduisme. Hal ini dapat dipahami bahwa sebelum Islam datang, kedua unsur tersebut sudah ada dan tertanam secara baik dalam kehidupan masyarakat. Memasukkan unsur-unsur Islam merupakan upaya untuk mengalihkan tempat meminta, dari makhluk-makhluk halus kepada Allah. Dari sisi ini masyarakat pengamal praktik ini, seperti ritual tolak bala memandang bahwa pekerjaan mereka tidak bersalahan dengan Islam. Pemahaman ini tentu saja merupakan dampak dari kurangnya pemahaman mereka terhadap aqidah Islam. Mereka juga tidak memahami bahwa strategi tersebut dilakukan hanyalah untuk sementara sambil menuju kepada pemahaman yang sempurna. Dengan kata lain, hal ini hanya merupakan langkah awal dan bukan hal yang telah dianggap selesai. Dengan demikian, pemanggilan berbagai macam roh halus dalam ritual tolak bala merupakan sesuatu yang bersalahan dengan aqidah Islam, karena masih meyakini adanya kekuatan lain selain Allah, dan juga meminta bantuan kepada selain Allah. Amran Kasimin menjelaskan bahwa penggunaan kalimat-kalimat Allah yang disertakan seruan kepada jin lebih

\footnotetext{
${ }^{71}$ Cukup banyak ayat al-Qur'an yang melarang manusia meminta atau berdoa kepada selain Allah, di antaranya: QS. Jin [72]: 6; QS. Yunus [10]: 106-107; QS. Al-Ankabut [29]: 5-6; QS. Shad [38]: 55. Demikian juga di dalam Hadits Nabi dinyatakan "Sesungguhnya jampi-jampi, azimat-azimat, dan guna-guna adalah syirik" (HR. Imam Abu Daud dan Imam Ahmad).
} 
banyak melahirkan kekeliruan, perilaku tersebut adalah mempermainkan kalimat-kalimat Allah (istihza'), menyalahgunakan sebutan nama Rasulullah dan kalimah syahadat. ${ }^{72}$

Setelah masyarakat Petalangan menganut agama Islam, kepercayaan asal mereka tidak lagi berfungsi sebagai agama, tetapi hidup pada garis pinggir (periphery) peradaban mereka. Kepercayaan kepada kekuatan-kekuatan gaib yang diyakini menguasai alam sekitarnya atau tempat-tempat tertentu yang dipandang mempunyai pengaruh bagi kehidupan manusia telah melahirkan berbagai upacara dan sastra lisan. Masyarakat Petalangan - dan masyarakat Suku Asli umumnya - membagi dunia ke dalam bagian-bagian tertentu dan dihuni oleh kekuatankekuatan gaib tertentu pula. Dari pembagian ini berkembang pula berbagai upacara yang dilakukan untuk kenyamanan kehidupan, baik berupa tolak bala (penyemahan/pemeliharaan) kampung, mati tanah di saat akan mendirikan rumah, tradisi pengobatan, dan upacara-upacara lainnya. Mereka percaya bahwa setiap makhluk, baik binatang maupun tumbuh-tumbuhan yang ada di dunia ini memiliki penjaga atau penguasanya yang disebut dengan okuan. Makhluk-makhluk gaib tersebut juga menjaga atau menguasai tempat-tempat tertentu. Di kalangan masyarakat Petalangan dikenal beberapa nama makhluk gaib, seperti jengkodi, mambang, ajo ikan, semangat insane boe padi, dan lain-lain.

Bertahannya unsur-unsur kepercayaan Hindu, animisme dan dinamisme di tengah masyarakat Petalangan tidak terlepas dari cara pengislaman dan corak Islam masuk ke kawasan ini. Hal ini merupakan fenomena umum yang terjadi di kawasan Asia Tenggara, di mana Islam yang datang adalah ajaran Islam yang mentoleran kepercayaan lama yang ada dalam masyarakat. ${ }^{73}$

\footnotetext{
${ }^{72}$ Amran Kasimin, "Mantera dari Perspektif Islam", dalam Pandangan Semesta Melayu Mantera, Penyelenggara, Rogayah A. Hamid dan Mariyam Salim (Kuala Lumpur: Dewan Bahasa dan Pustaka, 2007), 254-287.

${ }^{73}$ Azyumardi Azra, Renaisans Islam Asia Tenggara (Bandung: remaja Rosdakarya, 1999), 35; Muchtar Luthfi, Soewardi MS.
}

Hal ini tidak dapat disalahkan, karena strategi melakukan pengislaman secara bertahap dan mengakomodasi kepercayaan lokal yang tidak bertentangan dengan ajaran Islam secara langsung merupakan langkah yang bijak, agar masyarakat setempat tidak terkejut. Namun, langkah ini seharusnya dilanjutkan secara lebih intensif agar dari waktu ke waktu ada perbaikan pemahaman keagamaan di kalangan masyarakat. Hal inilah yang dimaksud oleh Azyumardi Azra dengan intensifikasi Islamisasi. ${ }^{74}$ Perubahan tersebut harus dilakukan secara berangsur-angsur, mengingat kepercayaan merupakan bagian dari inti kebudayaan atau disebut juga bagian dari sistem ide atau nilai atau covert culture atau culture system..$^{75}$ Di samping itu, kurangnya pemahaman masyarakat terhadap ajaran Islam dan rendahnya tingkat pendidikan juga turut menyumbangkan bertahannya tradisi ini.

\section{Kesimpulan}

Ritual tolak bala merupakan suatu tradisi yang sudah berlangsung sejak lama di masyarakat Petalangan dan tetap dipertahankan hingga saat sekarang. Ritual ini dilakukan dengan tujuan untuk menolak bala atau bencana, baik secara pribadi maupun kampung. Ritual tolak bala juga disebut sebagai kegiatan memelihara dan mengobati kampung. Di daerah lain di Provinsi Riau ada yang menyebut dengan menyemah kampung. Masyarakat Petalangan mempercayai bahwa seluruh makhluk di dunia ini ada yang menjaga atau yang menjadi pelindungnya yang disebut dengan okuan. Makhluk halus tersebut ada yang berkarakter baik dan ada yang buruk. Oleh karena itu, agar masyarakat dapat hidup dengan tenang dan damai serta terhindar dari berbagai bencana, maka mereka harus menjalin hubungan yang harmonis dengan makhluk-

\footnotetext{
\& Wan Ghalib et.al. (Penyunting), Sejarah Riau (Pekanbaru: Pemda Tk. I Riau, 1977).

${ }^{74}$ Azyumardi Azra, 27-47.

${ }^{75}$ Sugeng Pujileksono, Petualangan Antropologi (Malang: UMM Press, 2006), 34.
} 
makhluk halus tersebut.

Ritual tolak bala merupakan bentuk sinkretisme agama, yang terdiri dari ajaran Islam, Hindu, animisme dan dinamisme. Sinkretisme ini diwujudkan dalam bentuk kenduri tolak bala, di mana di dalam acara kenduri tersebut seluruh unsur ini menyatu sedemikian rupa. Maka tidak heran yang terlibat di dalam kegiatan ini adalah ustadz dan juga dukun. Unsur Islam dimasukkan sebagai bentuk peralihan agama masyarakat Petalangan yang sebelumnya menganut animisme dan dinamisme atau juga mungkin Hindu dan Budha. Mereka belum dapat meninggalkan kepercayaan lama secara sepenuhnya, sehingga unsur Islam ditempelkan dalam acara tersebut. Fenomena ini menjelaskan bahwa ritual tolak bala merupakan hasil dari akulturasi antara Islam dengan kepercayaan lama yang terdapat pada masyarakat Petalangan. Meskipun pada saat sekarang masyarakat Petalangan seluruhnya beragama Islam, namun belum semuanya melaksanakan ajaran Islam tersebut secara baik dan sempurna, sehingga masih ditemukan praktikpraktik yang bersalahan dengan aqidah Islam. Rendahnya pemahaman mereka terhadap ajaran Islam membuat ritual ini tetap berlangsung, dan masyarakat "takut" akan tertimpa bencana jika ritual ini tidak dilaksanakan.

\section{Daftar Kepustakaan}

\section{A. Djadja Saefullah. Pendekatan Kuantitatif dan}

Kualitatif dalam Penelitian Lapangan: Khusus dalam Studi Kependudukan. Bandung: Fakultas Ilmu Sosial dan Ilmu Politik UNPAD, 1993.

A. Mukti Ali. "The Evolution of Islam in Indonesia." Cultures VII, no. 4 (1980): 109-118.

Abdul Munir Mulkhan. Islam Murni pada Masyarakat Petani. Yogyakarta: Bentang Budaya, 2000.
Ahmad Kholil. "Seblang dan Kenduri Masyarakat Desa Olehsari: Relasi Ideal Antara Islam dan Budaya Jawa di Banyuwangi." ElHARAKAH 12, no. 2 (2010): 131-53.

Amran Kasimin. "Mantera dari Perspektif Islam". Dalam Pandangan Semesta Melayu Mantera. Penyelenggara, Rogayah A. Hamid dan Mariyam Salim. Kuala Lumpur: Dewan Bahasa dan Pustaka, 2007.

Arifuddin Ismail. Agama Nelayan: Pergumulan Islam dengan Budaya Lokal. Yogyakarta: Pustaka Pelajar, 2012.

Azyumardi Azra. Renaisans Islam Asia Tenggara. Bandung: remaja Rosdakarya, 1999.

Betty, Andrew. "Adam and Eve and Vishnu: Syncretism in the Javanese Slametan." The Journal of Anthropological Institute 2 (1996).

Bartholomew, John Ryan. Alif Lam Mim; Kearifan Masyarakat Sasak. Yogyakarta: Tiara Wacana, 2001.

Bogdan, R. \& S.J. Tylor. Kualitatif Dasar-dasar Penelitian (terjemahan). Surabaya: Usaha Nasional, 1993.

Dugang. "Sistem Kepercayaan dalam Pengobatan Tradisional (Studi Kasus Pada Komunitas Melayu Petalangan di Kabupaten Pelalawan)". Skripsi: Universitas Riau, 2011.

Edwin Fiatiano, et.al. "Makam Sunan Giri sebagai Objek Wisata Budaya". Dalam Kumpulan Abstrak Hasil Penelitian Universitas Airlangga. Surabaya: Lembaga Penelitian Universitas Airlangga, 1998.

Erni Budiwanti. Islam Sasak, Islam Wetu versus Wetu Telu. Yogyakarta: LkiS, 2000.

Geertz, Clifford. Islam Observed Religious Development in Morocco and Indonesia. Chicago \& London: The University of 
Chicago Press., 1971.

-----. Abangan, Santri, Priyayi dalam Masyarakat Jawa (terjemahan). Jakarta: Pustaka Jaya, 1989.

-------. Kebudayaan dan Agama (terjemahan). Yogyakarta: Kanisius, 1992.

Headley, Stepen. "The Islamization of Central Java: The Role of Muslim Lineage in Kalioso.” Studia Islamika 3, no. 2 (1997).

Hefner, Robert W. Hindu Javanese: Tengger Tradition and Islam. Princeton: Princeton University Press, 1985.

Hendro Prasetyo. "Mengislamkan Orang Jawa: Antropologi Baru Islam Indonesia." Jurnal Islamika, no. 3 (1993): 74-84.

Hikmatul Mustagfiroh dan Muhamad Mustaqim. "Analisis Spiritualitas Para Pencari Berkah (Studi Atas Motivasi Peziarah di Makam Sunan Kalijaga Kadilangu Demak)." Jurnal Penelitian 8, no. 1 (2014): 143-160.

Ismail Yakub. Sejarah Islam di Indonesia. Jakarta: Proyek Pengadaan Bahan Dakwah Depag RI, 1972.

Jalaluddin Rakhmat. "Islam di Indonesia: Masalah Definisi”. Dalam Islam di Indonesia: Suatu Ikhtiar Mengaca Diri. Ed. M. Amien Rais. Jakarta: Sri Gunting, 1996.

Judistira K. Garna. Metode Penelitian Pendekatan Kualitatif. Bandung: Primico Akademika, 1999.

Kamus Dewan. Edisi Keempat, Cetakan Ketiga. Kuala Lumpur: Dewan Bahasa dan Pustaka, 2010.

Kang, Yoonhe. Untaian Kata Leluhur: Marjinalitas, Emosi dan Kuasa Kata-kata Magi di Kalangan Orang Petalangan Riau (terjemahan). Pekanbaru: Pusat Penelitian Kebudayaan dan Kemasyarakatan
Universitas Riau, 2005.

Koentjaraningrat. Metode-metode Penelitian Masyarakat. Jakarta: Gramedia, 1991.

Lexy J. Moleong. Metodologi Penelitian Kualitatif. Bandung: Remaja Rosdakarya, 2000.

Mahmud Manan. "Nilai-nilai Budaya Peninggalan Majapahit dalam Kehidupan Masyarakat di Trowulan Mojokerta". Surabaya: Lembaga Penelitian IAIN Sunan Ampel, 1999.

Masdar Hilmy. "Akulturasi Islam ke dalam Budaya Jawa: Analisis Tekstual-Kontekstual Ritual Slametan." Jurnal Paramedia III, no. 1 (2001): 34-83.

Masyudi. "Ziarah ke Makam Islam Sunan Ampel Surabaya." Madaniyya, Jurnal Sastra dan Sejarah II, no. 2 (1999): 41-51.

Mohd. Taib Osman (ed.). Masyarakat Melayu Struktur, Organisasi dan Manifestasi. Kuala Lumpur: Dewan Bahasa dan Pustaka, 1989.

Muchtar Luthfi, Soewardi MS. \& Wan Ghalib et.al. (Penyunting). Sejarah Riau. Pekanbaru: Pemda Tk. I Riau, 1977.

Muhaimin AG. Islam dalam Bingkai Budaya Lokal Potret dari Cirebon. Jakarta: Logos, 2001.

Mulders, Neils. Agama, Hidup Sehari-Hari dan Perubahan Budaya. Jakarta: Gramedia Pustaka Utama, 1999.

Nakamura, Mitsuo. Bulan Sabit Muncul dari Balik Pohon Beringin. Yogyakarta: Gajah Mada University Press, 1983.

Noerid Halui Radam. Religi Orang Bukit. Yogyakarta: Semesta, 2001.

Norbeck, Edward. Religion and Human Life. New York: Holt, Rinehart and Winston Inc., 1974. 
Norhasan. "Tradisi Kadiran: Kajian Terhadap Pola Ritual dan Makna Simbolisnya." Jurnal Teosofi 2, no. 1 (2013): 50-66.

Nur Syam. Islam Pesisir. Yogyakarta: LkiS, 2005.

Parsudi Suparlan. Kebudayaan, Masyarakat dan Agama: Agama sebagai Sasaran Penelitian Antropologi. Jakarta: Depag RI., 1981

Roibin. "Dialektika Agama dan Budaya dalam Tradisi Selamatan Pernikahan Adat Jawa di Ngajum, Malang." El-HARAKAH 15, no. 1 (2015): 34-47.

Soerjono Soekanto. Emile Durkheim: Aturanaturan Metode Sosiologis. Jakarta: Rajawali Press, 1985.

Sudirman Shomary. "Nyanyian Panjang Orang Talang di Riau: Suatu Kajian Kes." Thesis: Universiti Kebangsaan Malaysia, 1998.

Sugeng Pujileksono. Petualangan Antropologi. Malang: UMM Press, 2006.

Suripan Sadi Hutomo. Sinkretisme Jawa Islam. Yogyakarta: Bentang Budaya, 2001.

Taufik Abdullah. "Islam dan Pembentukan Tradisi di Asia Tenggara: Sebuah Perspektif Perbandingan". Dalam Tradisi dan Kebangkitan Islam di Asia Tenggara. Eds. Taufik Abdullah \& Sharon Siddique. Jakarta: LP3ES. 1988.

Tenas Effendy. Sekilas tentang Orang Talang di Riau. Pekanbaru: Dewan Kesenian Riau, 1995.

-------. Adat Istiadat dan Upacara Perkawinan di Bekas Kerajaan Pelalawan. Pekanbaru: Lembaga Adat Daerah Riau, 1998.

------. “Orang Talang dan Kebudayaannya”. Makalah, 1998.

Bujang Tan Domang: Sastra Lisan Orang Petalangan. Cet. Ke-2. Jakarta: Yayasan Obor Indonesia, 2008.

Turner, Ashley M. "Cultural Survival, Identity and the Performing Arts of Kampar's Suku Petalangan”. BKI 153, no. 4 (1997): 648-71.

UU. Hamidy. Islam dan Masyarakat Melayu di Riau. Pekanbaru: UIR Press, 1999.

Woodward, Mark R. Islam Jawa Kesalehan Normatif Versus Kebatinan (terjemahan). Yogyakarta: LkiS, 1999. 